\title{
THE EQUITABLE LIABILITY OF STOCKHOLDERS; THE GROUNDS UPON WHICH IT RESTS.
}

Where creditors of a corporation seek to enforce the liability of stockholders for the debts of the corporation, the first thing to be determined is the nature of the liability; for upon that depends not only the form of the remedy to be adopted and the course of procedure to be pursued, but also whether the liability is enforceable in States other than that of the domicile of the corporation.

At common law a corporation is regarded as a person or entity entirely distinct from its members, who are considered as mere strangers so far as dealings between the corporation and third parties are concerned. A creditor of the corporation can enforce his claim only by proceeding against the corporation itself in an action at law, and, after reducing his claim to a judgment, by levying an execution on the property of the corporation.

It sometimes happens, however, that the only property which a corporation has is of such a nature that it cannot be taken in execution, as, for instance, where it consists of unpaid stock subscriptions. So, also, by the strict rules of the common law, the dissolution of a corporation works a total extinguishment of all debts due to or from it; and, as the corporation has ceased to exist, it cannot sue or be sued, and all its property becomes vested in other parties, its real estate in the grantor or his heirs, and its personal estate in the sovereign. ${ }^{1}$ In these and similar cases, there being no remedy at law, on principles of its own, courts of equity in this country will lay hold of such property at the suit of creditors and apply it toward the payment of the debts of the corporation; and the stockholders, therefore, to the extent of their indebtedness to the corporation are said to be liable in equity for the debts of the corporation. In modern times, moreover, the legislatures of the several States, either in the charters granted to corporations, or in general statutes, have provided that stockholders shall be personally liable for the debts of the corporation to an extent

${ }^{1}$ Angell \& Ames, Corp., sec. 779. 
varying in the different States. The liability of stockholders, therefore, is of two kinds, the Equitable Liability and the Statutory Liability.

It is proposed in this article to consider the equitable liability and the grounds upon which it rests.

The equitable liability arises from the fact that the stockholders have in their hands assets of the corporation, and consists in an obligation which courts of equity will enforce, to pay over to the creditors for the corporation money which they owe to the corporation. ${ }^{1}$ Their liability, therefore, is limited to the amount of corporate assets in their hands.

The general object of a bill brought by creditors of a corporation against its stockholders is to obtain satisfaction of their claims out of the corporate assets in the hands of the stockholders which the corporation itself ought to have collected and applied to the payment of its debts.

Courts of equity, in the exercise of their general jurisdiction, entertain bills of this character usually on either one of two grounds: first, on the ground that the assets of the corporation constitute a trust fund for the payment of its debts which the creditors seek to have applied to the payment of the entire corporate indebtedness; in other words, that the bills are brought to compel the execution of a trust; or, second, on the ground that the corporate assets are by reason of their nature incapable of being taken in execution so that the creditors have no remedy at law; in other words, that the bills are ordinary creditors' bills. ${ }^{2}$ These two classes of bills, although they resemble each other in some respects, differ in several important particulars. They are alike in that their general object is to compel the application of corporate property in the hands of stockholders to the payment of the corporate debts, and that as a general rule they can be maintained only by judgment creditors who have exhausted the remedies at law, and that as a general rule the corporation is a necessary party. The particulars wherein they differ are that where the bill is framed for the administration of a trust fund, (I) all persons interested in the fund must be

¿Patterson v. Lynde, 106 U. S. 519.

${ }^{2}$ The first of these two classes of bills is illustrated by the cases of Wood v. Dumimer, 3 Mason, 308, and Handley v. Stutz, I37 U. S. 366; the second by Ogilvie v. Knox Ins. Co., 22 How. U. S. 380, and Marsh v. Burroughs, I Woods, 463 . 
made parties, creditors as well as stockholders, one or more creditors, unless all are named, suing in behalf of all, whereas, in the case of a creditors' bill one or more judgment creditors may sue one or more stockholders; (2) the court proceeds in accordance with its own rules to wind up the business of the corporation by collecting all of its assets, ascertaining all of its creditors as far as possible, adjusting the equities between the parties and distributing the fund, whereas, in the case of a creditors' bill the court generally only decrees payment of the complainants' claims by such of the defendant stockholders as are found to be indebted to the corporation, to the extent of their indebtedness.

The capital stock of a business corporation stands in the place of, and is a substitute for, the individual responsibility of the members which exists in co-partnerships. It is a fund created at the time of the formation of the corporation for the purpose of prosecuting the business of the corporation, and consists of the money paid in or agreed to be paid in by the subscribers to the stock, for the shares for which they subscribed. Persons dealing with the corporation are presumed to understand the legal nature and incidents of such a body politic and to contract with reference to them, ${ }^{1}$ to be aware of the immunity of its stockholders from liability for its debts, and, in giving credit to the corporation, they are presumed to rely solely for payment of their claims upon the property of the corporation. The capital stock and property belong exclusively to the corporation but are held and employed for the benefit of the stockholders who have contributed their money for the purpose of thus having it held and employed for their own profit. But the interest of the stockholders is only the right to receive the dividends declared out of the profits and, upon the dissolution of the corporation, their proportion of the corporate property remaining after payment of the corporate debts. The claims of creditors, therefore, upon the property of the corporation are paramount to those of the stockholders and must be satisfied before the latter are entitled to receive anything; and from these considerations, principally, the American courts of equity have deduced and formulated the doctrine that in equity the capital stock and other property of a corporation, especially its unpaid subscriptions, constitute a trust fund for the payment of the debts of the corporation.

${ }^{1}$ Mumma v. The Potomac Co., 8 Pet. 28r. 
The origin of the trust fund doctrine has by some been referred to the case of Wood $v$. Dummer, ${ }^{1}$ decided by Judge Story in I824. While that case may have been the first in which the doctrine was judicially enounced and made the ground of decision and relief, the theory was put forward five years earlier in two cases in the Supreme Judicial Court of Massachusetts, Vose v. Grant, ${ }^{2}$ and Spear v. Grant, ${ }^{3}$ decided in 1819 , and cited by Judge Story in Wood v. Dummer as supporting his views in that case. All three of these cases grew out of the insolvency of the Hallowell and Augusta Bank and the withdrawal by the stockholders of threefourths of the capital stock without leaving sufficient assets with which to pay the outstanding bills of the bank.

In Vose v. Grant a bill-holder sued a stockholder who was also a director in an action of trespass on the case as for a breach of duty on the part of the defendant and the other directors and stockholders in dividing three-fourths of the capital stock of the bank among themselves without providing means for the payment of the bills of the bank, the declaration alleging that the capital stock was a fund for the payment of the bills of the bank and that it was the duty of the defendant and other stockholders to preserve such fund and provide means for the payment of the bills. One ground which the plaintiff's counsel seems to have taken, according to the report, was that the stockholders were liable for the misapplication of the fund as trustees of the capital for the payment of debts and then for the stockholders. It was held that the action would not lie. In the course of the opinion of Judge Jackson in which he pointed out that the only remedy for the creditors was in equity, he said: "At the time when the capital stock was divided among the stockholders, it is obvious that the holders of their bills had a better right to the money. The stockholders owned nothing but the residue of the capital after payment of all the debts of the bank." In Spear $v$. Grant the action was assumpsit, and it was again held that the action would not lie, but that the remedy was in equity. Chief Justice Parker said that "the stock ought undoubtedly to be considered as a pledge, as far as it will go, and if withdrawn before the debts are discharged there would seem to arise an equitable obligation on the part of the stockholders to account for so much as they originally consented to pledge."

\footnotetext{
${ }_{3} 3$ Mason, 308.

${ }^{2} 15$ Mass. 505 .

${ }^{3} \mathrm{I} 6$ Mass. 9.
} 
Then came the case of Wood v. Dummer, where some of the bill-holders of the bank brought a bill in equity against some of the stockholders to obtain payment of the bills out of the dividends of the capital stock of the bank received by the defendants upon the division of the stock among the stockholders. Judge Story in his opinion followed the lines marked out by the Massachusetts court in Vose v. Grant and Spear v. Grant, and seems to have gone no farther, except to expound the doctrine a little more fully and to designate the capital stock as a "trust fund" as well as a "pledge." "It appears to me," said he, "very clear upon general principles, as well as the legislative intention, that the capital of banks is to be deemed a pledge or trust fund for the payment of debts contracted by the bank. The public, as well as the legislature, have always supposed this to be a fund appropriated for such purpose. The individual stockholders are not liable for the debts of the bank in their private capacities. The charter relieves them from personal responsibility, and substitutes the capital stock in its stead. Credit is universally given to this fund by the public, as the only means of repayment. During the existence of the corporation it is the sole property of the corporation, and can be applied only according to its charter, that is, as a fund for payment of its debts, upon the security of which it may discount and circulate notes. Why, otherwise, is any capital stock required by our charters? If the stock may, the next day after it is paid in, be withdrawn without payment of the debts of the corporation, why is its amount so studiously provided for, and its payment by the stockholders so diligently required? To me this point appears so plain upon principles of law, as well as common sense, that I cannot be brought into any doubt, that the charters of our banks make the capital stock a trust fund for the payment of all the debts of the corporation. The billholders and other creditors have the first claims upon it; and the stockholders have no rights until all other creditors are satisfied. * * * If the capital stock is a trust fund, then it may be followed by the creditors into the hands of any persons, having notice of the trust attaching to it. As to the stockholders themselves, there can be no pretense to say that both in law and fact, they are not affected with the most ample notice." The corporations which the court had in mind were banks organized under the laws of Massachusetts, but the principle laid down has been deemed equally applicable to all business corporations. 
The trust fund doctrine as commonly formulated in the proposition "the capital stock of a corporation is a trust fund for the payment of its debts," has been criticised by some as inaccurate and misleading and wholly unnecessary as a ground of jurisdiction for the purpose of enabling a court of equity at the suit of creditors to reach corporate assets in the hands of stockholders and apply them to the payment of the corporate debts. But it has been accepted by the courts of this country with practical unanimity and. has the emphatic approval of eminent judges and text-writers; and it has become so completely established as a general principle in American equity and corporation law, that it is not to be lightly and airily brushed aside as incorrect, confusing and useless. Its terms may be susceptible of various definitions taken singly, but the true meaning and scope of the proposition cannot be ascertained by subjecting it to the test of a rigid definition by scholastic methods. Considering the legal nature of a corporation, the relations which the corporation, the stockholders and the creditors sustain to the corporate property and to each other, the proposition seems to the writer to be a convenient, concise and reasonably clear statement of a general truth expressive of the existence of some special rights on the part of the creditors on the one hand, and of corresponding obligations on the part of the corporation on the other, in respect of some specific corporate property, which rights and obligations are recognized and enforced by courts of equity but not ordinarily by courts of law. The term "trust fund" is not meant to convey the idea that there is an express, technical trust, implying the existence of two estates, the legal title to the property in the corporation as trustee and the beneficial ownership thereof in the creditors, as cestuis que trust. The word "trust" is often used in a very broad and comprehensive sense, and is applied to a great variety of cases where one person holds property which he is bound to apply for the benefit of another, is an executor, administrator, surviving partner and agent.

Trusts which arise by operation of law form an important part of the general law of trusts. Of this class are constructive trusts, in the broad sense of the term,--those trusts which courts of equity raise or create for the purpose of protecting and establishing rights and enforcing obligations in respect of some particular property by means of those efficient remedies which they apply in cases

${ }_{2}^{2}$ Kent, Com. *307, n (b) ; Angell \& Ames, Corp., sec. 779 a. 
where similar rights and obligations arise from express trusts. ${ }^{1}$ These rights and obligations may arise in various ways, from contract or from fraud; they may be created by statute or by the common law; or they may owe their existence entirely to the doctrines of equity. In these cases the nature and extent of the trust are measured by the nature and extent of the rights and obligations.

In building up this remedial system of constructive trusts, courts of equity went a step further in applying the theory of a trust to cases which were not trusts, and invented or borrowed from the Roman law the doctrine of equitable liens. The cestui que trust under an express trust has an estate or interest in the property which is the subject of the trust. $\mathrm{He}$ is in equity deemed to be the true owner, and by virtue of that ownership may follow the property and assert his right therein against all persons into whose hands it may come except bona fide purchasers for value and without notice. In some cases which come within the class of constructive trusts, a party is considered as having an equitable estate in the property, either as the result of a contract relating to the property, or as the result of fraud in its acquisition by another. There are, however, other transactions relating to property where personal obligations (usually the payment of money) on the part of one party are incurred, but no interest or estate in the property is created in the other party, or in the party to be benefited by a performance of the obligations, and where, from the nature of the transaction, equity considers that such other party ought, in right and justice, to have a right of priority of payment out of the property over general creditors, and to follow it into the hands of any other person not a bona fide purchaser for value and without notice, and to subject it to the satisfaction of his claim.

The doctrine of "equitable liens" afforded courts of equity a ground on which to proceed in cases of this sort consistently with the principles of equitable jurisdiction. An equitable lien, although it is neither a right in a thing-ownership or property, nor a right to recover possession of it,-neither jus in re nor jus ad rem-is, nevertheless, a valuable right in the nature of property analogous to the right of a mortgagee in equity. It has been defined to be "a right not recognized at law, to have a fund or specific property or

${ }^{I_{I}}$ Spence, Eq. Jurisd., ${ }_{511} ;$ Hill, Trustees, ${ }^{*}{ }_{144}, *^{*} 7 x$; Snell, Principles of Eq. (3d ed.), rog. 
its proceeds applied in whole or in part, to the payment of a particular debt or class of debts." 1 The relations existing between the party in whose favor the lien exists and the owner of the property resemble those existing between the cestui que trust and the trustee in an express trust, and from time immemorial equitable liens have been regarded as belonging to the class of constructive trusts, the legal owner of the property being a trustee for the creditor to the extent of the lien. ${ }^{2}$

In view of the legal nature and incidents of a business corporation and the relative rights and duties of the corporation, its stockholders and its creditors, as established by judicial decisions, the trust fund doctrine is perfectly consistent with the theory on which courts of equity exercise jurisdiction in cases of implied trusts, and it is difficult to see how it is any more misleading and confusing than are other principles and doctrines of the law, the existence of which is not questioned, but the application of which in particular cases occasions some diversity of judicial opinion.

Corporations created for the purpose of carrying on business for pecuniary profit are required to establish a fund, called the capital stock, of a fixed amount, which is divided into shares and is obtained by subscriptions for the shares. At the inception of the corporation the subscribers become severally bound by a contract with it to pay the amount of the par value of the shares for which they have severally subscribed. The subscribers thereupon become stockholders and the aggregate amount of their subscriptions paid in or agreed to be paid in constitutes the capital stock of the corporation in the proper sense of that term. ${ }^{3}$ It is a fund created for the purpose of prosecuting the enterprise for which the corporation was formed, such as buying property, paying for labor and services, and especially for paying the debts and liabilities of the corporation. Indeed, it may be said that the fund is established for the sole purpose of being held as a security for the debts of the corporation to be applied to the satisfaction thereof in the event of the insolvency or dissolution of the corporation. The stockholders not being individually liable for the corporate debts, creditors can look only to the corporate property for the payment

\footnotetext{
${ }^{1}$ I3 Am. \& Eng. Ency. Law, p. 608.

${ }^{2}$ Pom. Eq. Jur., secs. I65, I,234; Story, Eq. Jur., sec. I,244; Hovey v. Elliott, II8 N. Y. I24.

${ }^{8}$ Cook, Corp., sec. 9 ; 2 Clark \& Marshall, Priv. Corp., sec. 375.
} 
of their claims. For this reason the capital stock is established at a fixed amount and required to be maintained intact, and, as was said by Parker, C. J., in Spear v. Grant, supra, "ought to be considered as a pledge." It cannot rightfully be withdrawn or diminished, or be used for any other purposes than such as are authorized by the charter, or parted with except for a valuable consideration, nor can the liability for stock subscriptions be released or cancelled or evaded by any simulated payment of such subscription or by any device short of actual payment in good faith. When debts are incurred, a contract at once arises with the creditors that the fund shall not be withdrawn or applied otherwise than upon their demands until such demands are satisfied. The creditors have a lien upon it in equity, and if diverted they may follow it as far as it can be traced, and subject it to the payment of their claims, except as against holders who have taken it bona fide for a valuable consideration and without notice. ${ }^{1}$

When the capital stock has been paid in and converted into other forms.of property, then such property and the earnings, if any, derived from the business, all the assets of the corporation, to the extent of the amount of the capital stock, represent, and to all intents and purposes, constitute, the capital stock. If a part only of the subscriptions has been paid in, then the unpaid subscriptions together with all other corporate property to the extent of the balance of the amount of the capital stock constitute the capital stock. In short, the capital stock is a fund of a fixed amount and of permanent duration, whether it remains in its original form or has been converted into or invested in other property. Such being the nature of the capital stock and the rights and obligations of the corporation, the stockholders and the creditors in relation thereto, when the corporation becomes insolvent and the creditors have exhausted their remedies at law without obtaining satisfaction of their claims and a portion of the capital stock is in the hands of the stockholders in the form of unpaid subscriptions which cannot be reached by execution, it would seem to be in accordance with the principles and practice of courts of equity, in order to afford a remedy, to resort to the doctrine of equitable liens and the theory of trusts, as they have done in many other instances of constructive

${ }^{1}$ Curran v. State of Arkansas, I5 How. 304; New Albany v. Burke, II Wall. 96; Burke v. Smith, 16 Wall. 390; Sawyer v. Hoag, I7 Wall. 610; Upton v. Tribilcock, 9I U. S. 45; Sanger v. Upton, 9I U. S. 56; Camden v. Stuart. I44 U. S. 104; Pom. Eq. Jur., sec. I,046. 
trusts, and enforce the lien by laying hold of the fund; and applying it to the purposes for which it was originally established. Especially would this be so where the corporation has been dissolved leaving debts and assets. ${ }^{1}$

There is a marked distinction in the books between a case where one takes property subject to a charge for the payment of debts or other charges in favor of third persons, and a case where one takes property in trust to pay the debts or charges. In the former case the holder of the property has the entire legal and beneficial interest in it subject only to the payment of the debts or other charges; in the latter case there is an express, direct trust to pay the debts or charges, the holder of the property having the legal title to it, while the beneficial interest is in the creditors or parties in whose favor the charge is created as cestuis que trust. ${ }^{2}$

Referring to cases of the former kind, where the holder of the property has the entire legal and beneficial interest in it subject to a charge only, Judge Story says: "In such cases, although the charge is treated, as between the immediate parties to the original instrument, as an express trust in the property, which may be enforced by such parties or their proper representatives; yet, as between the trustee and the cestuis que trust, who are to take the benefits of the instrument, it constitutes an implied or constructive trust only; a trust raised by courts of equity in their favor, as an interest in rem, capable of being enforced by them directly by a suit brought in their own names and right. ${ }^{8}$

The capital stock of a corporation, although it is a fund established for the prosecution of the corporate business and owned exclusively by the corporation, is a "trust fund" for creditors in the sense that it is subject to a charge in favor of creditors for the payment of debts in the event of the insolvency or dissolution of

'Story, Eq. Jur., sec. 1,252; Snell, Principles of Eq. (3d ed.), I09. Mr. Pomeroy has clearly shown how the theory of trusts, the notion of double ownership, has been extended by courts of equity to cases analogous to actual trusts, and thus given rise to that large class of cases called trusts arising by operation of law, such as the administration of estates of deceased persons, fiduciary relations, mortgages, equitable liens, etc., in which the use of the terms "trust," "trustee" and "trust fund" is as common and well established as the cases in which they are applied; and, it may be added, their meaning as well understood. Pom. Eq. Jur., secs. 147, I69.

${ }^{2}$ King v. Denison, I Ves. \& Beam. 273; Pom. Eq. Jur., sec. 1,244; Story, Eq. Jur., secs. I,244, I,245.

'Story, Eq. Jur., sec. I,244. 
the corporation. The trust consists in the obligation on the part of the corporation to preserve the fund, to do nothing that will destroy or diminish it to the end that it may be forthcoming upon the insolvency or dissolution of the corporation and applied to the payment of the corporate debts. Although the corporation has the use of the fund for the purpose of carrying on its business, yet, as it cannot rightfully pay it away without a valuable consideration, and every expenditure is made presumably in accordance with its charter and the law and for an equivalent in value in some form, as for property purchased, or for labor or services by which the value of the property is enhanced or profits are made, the fund, the capital stock, is not diminished but remains for the security of creditors until the insolvency or dissolution of the corporation en. titles the creditors to have it applied to the payment of their claims.

The debts secured by the charge on the capital stock of the corporation are the debts of the corporation itself (the trustee). There being privity of contract between it and the creditors, the relations existing between them are those, merely, of debtor and creditor, so that for the collection of their claims the creditors have open to them all the ordinary remedies afforded by the courts of common law, and, as in the case of claims against natural persons; the creditors are bound to exhaust their legal remedies against the corporation before they can come into equity for assistance. $\mathrm{Ob}$ taining a judgment at law on his claim and the return of an execution unsatisfied have always been necessary steps for a creditor to pursue before a court of equity would interfere in his behalf to enable him to obtain satisfaction of his claim out of his debtor's property which could not be reached by ordinary legal process. They establish the validity and amount of his claim and make his lien complete and ripe for enforcement, and a bill in equity by a creditor against the stockholders to reach the corporate assets in their hands is in effect a proceeding in rem, to enforce his charge or lien upon the capital stock. In compelling stockholders to account for unpaid subscriptions in such a suit, the court will give effect to the rights of creditors and enforce the obligations of the corporation to preserve and protect the capital stock for the benefit of creditors, by inquiring into the validity of past transactions between the corporations and the stockholders respecting the subscriptions as far back even as the making of the contract of subscription, and avoid all arrangements, contracts, releases and things done in violation of the principle that the capital stock is a trust fund for the benefit of the 
creditors. "Unpaid subscriptions are assets," says Chief Justice Fuller, in Hawkins v. Glenn," "but have frequently been treated by courts of equity as if impressed with a trust $s u b$ modo, upon the view that the corporation being insolvent the existence of creditors subjects these liabilities to the rules applicable to funds to be accounted for as held in trust."-

It has been objected, however, that the trust fund theory is unnecessary as a ground of jurisdiction in such cases in order to reach unpaid subscriptions, since a bill could be maintained on the ground of fraud and that particular phase of fraud which consists of a virtual misrepresentation of a fact, namely, that the capital stock has all been paid in, whereby the creditors have been induced to give credit to their injury, a case where equity will compel the offending party to make good his representations. There is no doubt that in most cases which contain the element of fraud a court of equity will entertain a bill for relief on that ground alone. But the difficulty is that in many instances of creditors' suits against stockholders there is no fraud whatever on the part of the stockholders even in the broad sense in which fraud is understood in equity. Corporations are not always required to have all their capital stock actually paid in before they can transact business. Unless otherwise provided in their charters or by general statutes they may, and generally do, if the full amount of the capital stock has been subscribed and thus secured by a valid contract, commence business and call in the capital as it may be required. In such cases, there being no obligation to pay in the capital, at least until calls have been made, there can be no implied representation made by the stockholders that they have paid the full amount of their subscriptions, nor any implief representation by the corporation that the capital stock has been all paid in; and it would be stretching "equitable fraud" a little too much to impute fraud to stockholders who have become such by a transfer of shares after the debts have been contracted. ${ }^{2}$

The legal nature of a corporation and the relations existing between it and its stockholders and creditors are the same in equity as at law. The corporation is in equity as at law an entity or person entirely distinct from the stockholders. It is the sole owner,

${ }^{1}$ I3I U. S. 3I9.

'See XII Yale Law Journal, 63, December, 1902, where the objections to the fraud theory were clearly stated. 
legal and equitable, of its property. If the stockholders owe any part of their subscriptions they are debtors to the corporation to the extent of the amount unpaid for which they may be sued by the corporation in an action at law. The consequences of a dissolution of a corporation are also the same at law and in equity. But just at the point where the powers of the courts of common law cease, where their forms of action and processes can furnish no remedy against either persons or things, equity steps in, and by giving effect to rights and obligations unknown to the common law, by its own flexible remedies, lays hold of the fund itself, in the familiar and expressive language of equity lawyers, and applies it to the discharge of obligations by which it is bound, as if (quasi) there was a trust.

In Wood v. Dummer, supra, the corporation had ceased to exist by the expiration of the time limited by its charter, and it was expressly stated by the court that there was no evidence whatever of fraud in the case. Hence, the title of the complainants to relief was put upon the ground "that the defendants held a trust fund applicable to the payment of the debts of the corporation." The bill was brought by some of the creditors against some of the stockholders, not by the plaintiffs in behalf of themselves and all other creditors, and contained no averment excusing the omission of creditors and stockholders not made parties. The relief prayed for was that the plaintiffs might be "reimbursed by the defendants out of the dividends of the capital stock received by them, the amount of the debts so due to the plaintiffs respectively for the bank notes above stated." Judge Story, however, treated the bill as being one where the whole fund was before the court for distribution among all the creditors, and where, although all interested in the fund, the corporation (if in existence) as well as the stockholders and creditors, should be made parties, they were too numerous for all to be so made and some of them might be dispensed with, and the court could do equity to those before it without prejudice to the rights of those not represented. 1

There is some apparent confusion in the decisions in regard to the grounds on which creditors' bills against stockholders are maintainable as well as in regard to the frame of the bill, the necessary parties and the necessary allegations. This seems to arise from not observing or bringing out clearly the distinction before mentioned

'Story, Eq. P1., secs. II9, I28. 
between the two classes of bills, namely, those grounded on the trust fund theory which seek to have the whole fund distributed among those entitled to it, and ordinary creditors' bills which merely ask to have debts due from the defendants to the corporation applied to the payment of the debt due from the corporation to the plaintiff; and it must be confessed that in cases of the latter kind courts have frequently proceeded on the ground that assets sought to be reached were a trust fund for creditors.

Where the object of the bill is to have the whole fund distributed among the creditors the fundamental rule of pleading requires that all persons who are interested in the fund or whose rights may be affected by the decree should be made parties. The bill, therefore, must be brought by all of the creditors, or by one or more in behalf of all. ${ }^{1}$ As to the stockholders it would seem on principle that all should be made parties, or their omission excused by proper averments, as that they are insolvent or out of the jurisdiction of the court. ${ }^{2}$

In Hatch v. Dana, ${ }^{3} \mathrm{Mr}$. Justice Strong, speaking for the court, said: "It may be that if the object of the bill is to wind up the affairs of this corporation, all the shareholders, at least so far as they can be ascertained, should be made parties, that complete justice may be done by equalizing the burdens, and in order to prevent a multiplicity of suits." The corporation, if in existence, is a proper party, but whether a necessary party or not there is diversity of opinion, some holding that where it is hopelessly and notoriously insolvent, and that fact is alleged in the bill, it need not be joined; others, that it should be a party because it is the owner of the property. The bill should allege, or at least it should be made to appear from facts which are alleged, that the plaintiffs are judgment creditors who have exhausted their legal remedies by executions returned unsatisfied. This requirement has few exceptions, since the judgments establish the validity and amount of the debts and the return of the executions shows the existence of facts necessary to give the court jurisdiction. So also it must appear by the bill that the unpaid subscriptions are a trust fund in the hands of the defendants applicable to the payment of the debts of the corporation. In Wood $v$. - Dummer, Judge Story said, referring to the loose manner in which the bill was drawn: "It does not directly proceed upon the ground

${ }^{2}$ Handley v. Stutz, I37 U. S. 366.

'Wood v. Dutnmer, supra.

'tor U. S. 205. 
that the defendants hold a trust fund applicable to the payment of the debts of the corporation; but leaves this to be picked up in fragments by a minute analysis of the bill." And again: It "does not charge that the capital stock is a trust fund appropriated by law and the charter to the payment of the debts, and that the surplus only, after such payment, belongs to the stockholders. Such an allegation was most fit to have been made upon the grounds on which ultimately the plaintiffs concluded to rest their case at the hearing. The court is therefore compelled to thread it out by inference and intendment and exposition of the charter, as made part of the pleadings." 1 So also it must be made to appear that the corporation is insolvent, or that it is dissolved, and that there is no other property out of which the debts can be paid.

An ordinary creditors' bill may be brought by one or more judgment creditors for their own benefit, or by one or more in behalf of themselves and all other creditors against one or more stockholders, ${ }^{2}$ and generally the corporation is a necessary party. It must be alleged that the plaintiffs are judgment creditors and that executions on their judgments have been returned unsatisfied.

In many of the cases of this sort, as above intimated, although the bills are brought by one or more creditors for their own benefit exclusively against one or more stockholders, and ask for payment of their debts alone, they set out and claim that the unpaid subscriptions are a trust fund for the payment of the debts of the corporation, and the courts in their opinions and decisions seem frequently to go upon that theory as though the existence of a trust was necessary in order to give them jurisdiction and enable them to grant relief. Marsh v. Burroughs, ${ }^{3}$ is an example. The bill charged that the unpaid subscriptions constitute a trust fund and prayed that it might be so decreed and might be applied to the payment of the plaintiffs' claims. The court appears to have sustained the bill as framed on the ground that the unpaid stock subscriptions were a trust fund. On the other hand, in Ogilvie $v$. Knox Ins. Co., the bill was filed by certain judgment creditors in behalf of themselves and such other creditors as might make themselves parties against the corporation and some of the stockholders. It alleged that the complainants had recovered judgments against

'See also Handley v. Stutz, supra.

'Marsh v. Burroughs, I Woods, 463; Ogilvie v. Knox Ins. Co., 22 How.

${ }^{3}$ I Woods, 463 .

'22 How. 380 . 
the company on which executions had been returned unsatisfied and that the defendants other than the company severally subscribed for stock in the company and were still indebted for it, payment not having been enforced by the company. The prayer was that the defendant stockholders might be decreed to pay their subscriptions and that the judgments might be satisfied from the fund thus produced. The court proceeded solely upon the theory upon which the bill was framed, namely, that the defendant stockholders were debtors to the company for the several amounts due by each for unpaid subscriptions. Mr. Justice Grier, writing the opinion of the court says: "This bill is filed to compel these stockholders or debtors to the corporation to pay the amount of their debts, in order that the creditors of the company may obtain satisfaction." And again: "As stockholders who have not paid in the whole amount of the stock subscribed and owned by them, they (the defendant stockholders) stand in the relation of debtors to the corporation for the several amounts due by each of them. As to them, this bill is in the nature of an attachment, in which they are called in to answer as garnishees of the principal debtor."

In Hatch $v$. Dana, ${ }^{1}$ although the bill in that case has been said to be a bill for the administration of a trust fund for the benefit of all the creditors, ${ }^{2}$ nevertheless the court emphatically called it "an ordinary creditors' bill, the sole object of which is to obtain payment of the complainant's judgment," declaring that it was not a bill seeking to wind up the company, and proceeded on the ground that the defendants' unpaid subscriptions were merely debts due to the corporation which a judgment creditor could reach by a creditor's bill, taking the same view that the court took in Ogilvie $v$. Knox Ins. Co., supra. "By his subscription," says Mr. Justice Strong, "each [subscriber to the capital stock] becomes a several debtor to the company, as much so as if he had given his promissory note for the amount of his subscription. At law, certainly, his subscription may be enforced against him without joinder of other subscribers; and in equity his liability does not cease to be several. A creditor's bill merely subrogates the creditor to the place of the debtor, and garnishes the debt due to the indebted corporation. It does not change the character of the debt attached or garnished."

Perhaps the reason why ordinary creditors' bills are so often found to contain averments of a trust is that formerly, and until a

'Ior U. S. 205.

${ }^{2}$ Handley v. Stutz, supra. 
recent period, it was a vexed question whether an ordinary creditors' bill could be maintained to reach choses in action unless it showed fraud or a trust or some recognized ground of equitable jurisdiction other than the absence of any remedy at law. ${ }^{1}$ The view that such a bill will not lie unless fraud or a trust is shown is maintained by some courts to-day, ${ }^{2}$ although it is generally held that such a bill will lie on the ground of the inability of the courts of common law to afford a remedy by which a debtor's property of an intangible nature, such as choses in action, can be reached and subjected to the payment of his debts. ${ }^{3}$ In some jurisdictions, therefore, it might have been, and may be still, necessary or prudent in ordinary creditors' suits to adopt the trust fund theory in framing the bill and to aver or set out in substance the existence of the trust.

The Supreme Court of the United States has emphatically declared that the unpaid subscriptions to the capital stock of a corporation are a trust fund for the benefit of all the creditors equally, and cannot be appropriated by any one creditor exclusively to himself, and that for that reason no stockholder in a suit by or in behalf of all the creditors to enforce his subscription liability has a right to set off against that liability an ordinary debt of the corporation, and no creditor of a corporation can maintain an action at law against any stockholder on his subscription liability, to recover the debt due to him from the corporation." In view of these decisions there seems to be an inconsistency in permitting a single creditor, by bringing an ordinary creditors' bill for his own benefit exclusively, actually to obtain a preference over other creditors, especially where the bill shows upon its face that the money which the plaintiff seeks to have applied to the payment of his claim is unpaid subscription money and a trust fund for all the creditors equally.

The inconsistency, however, is apparent rather than real. The general rule undoubtedly is that all persons materially interested in the subject-matter of a suit, such, for instance, as a particular fund for the payment of debts or legacies, ought to be made parties, to the end that no injustice will be done by the decree to absent parties; and on a bill filed by a single creditor of a corporation against stock-

$1^{2}$ Kent, Com., 442, 443.

${ }^{2}$ Greene v. Keene, 14 R. I. 338.

'Pom. Eq. Jur., sec. r,4I5, and the modern text books on equity.

'Sawyer v. Hoag, I7 Wall. 6Io; Scoville v. Thayer, 105 U. S. I43; Patterson v. Lynde, 106 U. S. 519. 
holders to obtain payment of his own debt only, the court will not decree payment of the debt if it appears that there are persons other than the plaintiff who have claims upon the fund, and that the fund is or may be insufficient for the payment in full of all having claims upon it, but on the contrary will frame the decree so that all of the creditors may come in and share in the distribution of the fund.

The practice, however, seems to be for the court to presume in case of such a bill, unless the contrary appears affirmatively on the bill, answer, or proofs, that there are no other creditors, or if there might be some, that there will be no deficiency of assets. ${ }^{1}$

In Marsh v. Burroughs this very matter was discussed by the court. Mr. Justice Bradley said: "When a case exists in which a fund can only be divided satisfactorily among a certain class, it is necessary to frame the decree in such a manner as that all those persons may be brought in for their distributive shares; but even then, the bill may often be filed by any one of them on his own behalf. It is only when it appears to the court by the subsequent pleadings, or otherwise, that a distribution must be made (as when an executor pleads want of sufficient assets) that a decree will be made for the benefit of all."

It was the purpose of the writer to conclude this paper by taking up a few illustrative cases, especially those decided by the Supreme Court of the United States, involving questions touching the equitable liability of stockholders, with a view of ascertaining, if possible, the extent of that liability, or, more accurately perhaps, when or under what circumstances short of actual payment in full for stock is no liability incurred, or if incurred, does the liability cease, or do the courts refuse to enforce it against stockholders. But this article has already reached, if it has not exceeded, its just limits, and such a review of the cases must be reserved for some other occasion. It seems proper, however, in closing, to observe that in a majority of the cases the creditors sue the stockholders on their subscription liability, a liability which is attached to the stock and follows it into whosesoever hands it may go, and that in such suits a defendant stockholder may be an original subscriber to the stock who has not paid for it, or he may be a remote purchaser or transferree of the stock who bought it in good faith and for fair value. These considerations suggest

${ }^{2}$ Story, Eq. Pl., secs. 99, roo, and notes; Hallett v. Hallett, 2 Paige, I5; Marsh v. Burroughs, $\nabla$ Woods, 463. 
the extent of the liability and the lines upon which an examination of the cases might be directed; and the following extract from the opinion of the court in the case of Camden $v$. Stuart, ${ }^{1}$ may fitly conclude this article:

"It is the settled doctrine of this court that the trust arising in favor of creditors by subscriptions to the stock of a corporation, cannot be defeated by a simulated payment of such subscriptions, nor by any device short of an actual payment in good faith. And while any settlement or satisfaction of such subscription may be good as between the corporation and the stockholders, it is unavailing as against the claims of the creditors. Nothing that was said in the recent cases of Clark v. Bever, I39 U. S. 96; Fogg v. Blair, I39 U. S. II8; or Handley v. Stutz, I39 U. S. 4I7, was intended to overrule or qualify in any way the wholesome principle adopted by this court in the earlier cases, especially as applied to the original subscribers to stock. The later cases only intended to draw a line beyond which the court was unwilling to go in affixing a liability upon those who had purchased stock of the corporation, or had taken it in good faith in satisfaction of their demands."

Providence, R. I., September, Ig03.

George B. Barrowes.

${ }^{2}$ I44 U. S. 104, II3. 